EUROPA REGIONUM TOM XXII ROK 2015

DOI: $10.18276 /$ er.2015.22-05

\author{
WIOLETTA KNAPIK
}

Kraków

\title{
Zmiany na polskiej wsi w perspektywie Programu Rozwoju Obszarów Wiejskich na lata 2014-2020
}

\section{Wprowadzenie}

ozwój obszarów wiejskich, rozumiany jako rozwój społeczny, łączy
w sobie wiele elementów, które współwystępuja, przenikają sie i nawzajem na siebie oddziałują. Najważniejszym obszarem jest gospodarka, ale nie mniej istotne są zmiany zachodzące w sferze społeczno-kulturowej. Rozwój ten musi uwzględniać realia demograficzne, procesy urbanizacyjne zachodzące na wsi, jak również cele i standardy, które narzuca Unia Europejska. Jaka jest zatem perspektywa rozwoju polskich obszarów wiejskich? Próba określenia kierunków tego rozwoju podjęta została na podstawie polityki UE, realizowanej w ramach m.in. Programu Rozwoju Obszarów Wiejskich. Przyszłość obszarów wiejskich jest ściśle związana z podmiotową rolą lokalnych społeczności, które inicjują zmiany i przyczyniają się do bardziej efektywnego wykorzystania zasobów, zgodnie z zasadą neoendogennego rozwoju. 


\section{Rozwój obszarów wiejskich na tle koncepcji neoendogennego rozwoju}

Neoendogenny rozwój ukierunkowany jest na realizację potrzeb społeczności lokalnych i opiera się na zaangażowaniu i współdziałaniu różnych aktorów społecznych, reprezentujących sektory: publiczny, gospodarczy, społeczny. Dzięki decentralizacji oraz delegacji odpowiedzialności na szczebel regionalny i lokalny możliwe jest kreowanie i wspieranie oddolnego procesu decyzyjnego. Koncentracja na problemach lokalnych oraz włączanie społeczności do polityki zarządzania rozwojem regionalnym powoduje, iż procedury biurokratyczne są mniej skomplikowane, ukierunkowane na specyficzne potrzeby mikroregionów. Warta podkreślenia jest inicjatywa lokalnych wspólnot w zakresie absorpcji środków unijnych na etapie tworzenia procedur oraz monitorowania i ewaluacji wniosków o przyznanie funduszy. Neoendogenny rozwój, dzięki transferowi wiedzy naukowej, połączonej z lokalnymi doświadczeniami, sprzyja wielofunkcyjnemu rozwojowi, a w szczególności przyczynia się do: kreowania zrównoważonego systemu zarządzania gruntami rolnymi, budowania społeczeństwa obywatelskiego, planowania strategii zrównoważonego zarządzania zasobami, ochrony środowiska naturalnego i utrzymania bioróżnorodności, rozwoju nierolniczej gospodarki i produkcji regionalnej żywności ${ }^{1}$.

Zdaniem Christophera Ray'a wyzwaniem dla neoendogennego rozwoju w krajach UE jest stworzenie koherentnej teorii oraz „sposobu działania” (modus operandi) we współczesnych warunkach społeczno-gospodarczych. Obszary wiejskie nie są jednolite (C. Ray nazwał je „mozaiką obszarów/regionów” „a mosaic of local/regional territories”), dlatego wymagają zróżnicowanego podejścia, decentralizacji polityki i scedowania na lokalne społeczności części odpowiedzialności za własny rozwój. Neoendogenny rozwój jest alternatywnym podejściem wobec polityki centralnej zakładającej, że wszelkie problemy natury społecznej lub gospodarczej mogą być rozwiązywane z użyciem standardowych środków, nieuwzględniających lokalnych uwarunkowań. Po pierwsze: rozwój powinien być zorientowany na maksymalizację zysków konkretnego regionu/obszaru dzięki wykorzystaniu lokalnych zasobów; po drugie: powinien mieć

1 T. Adamski, K. Gorlach, Koncepcja rozwoju neoendogennego, czyli renesans znaczenia wiedzy lokalnej, w: Socjologia jako stużba społeczna, red. K. Gorlach, M. Niezgoda, Z. Seręga, Wydawnictwo Uniwersytetu Jagiellońskiego, Kraków 2007. 
kontekstualny charakter, co oznacza skupienie się na potrzebach, zasobach i perspektywach rozwoju lokalnych wspólnot ${ }^{2}$.

\section{Program Rozwoju Obszarów Wiejskich: ocena efektywności PROW 2007-2013 oraz perspektywa na lata 2014-2020}

Kierunki rozwoju polskiej wsi, w najbliższej przyszłości, będą silnie powiązane, podobnie jak w ostatnim dziesięcioleciu, z dotacjami unijnymi, które przeznaczone są na konkretne działania mające na celu wspomaganie i promowanie wielofunkcyjnego rozwoju, przedsiębiorczości oraz aktywizacji społeczności lokalnych. Działania te realizowane są w ramach Wspólnej Polityki Rolnej (WPR), której jednym z instrumentów jest Program Rozwoju Obszarów Wiejskich (PROW).

PROW to unijny program, który oferuje wsparcie rozwoju europejskich obszarów wiejskich w zakresie: a) inwestycji w rolnictwie i przetwórstwie poprawiających konkurencyjność sektora rolno-spożywczego; b) udzielania pomocy inwestorom, którzy tworzą nowe miejsca pracy na obszarach wiejskich; c) rozwoju ekologicznych metod gospodarowania oraz przedsięwzięć chroniących naturalne środowisko i walory wiejskiego krajobrazu; d) „odnowy wsi”, na działania poprawiające jakość życia jej mieszkańców oraz wdrażanie zespołowych inicjatyw rozbudzających aktywność lokalnych społeczności ${ }^{3}$.

Wszystkie działania są finansowane z Europejskiego Funduszu Rolnego na Rzecz Rozwoju Obszarów Wiejskich oraz współfinansowane z krajowego budżetu. Środki, którymi dysponowała Polska w ramach PROW na lata 20072013, wyniosły ok. 28,6 mld euro ${ }^{4}$.

A jaka była efektywność PROW mierzona absorpcją tych środków i ich inwestycją?

a) w pierwszych trzech latach zostało wydatkowanych jedynie 9\% środków;

b) prawie połowa środków została wydatkowana dopiero po 2011 roku;

2 C. Ray, Neo-endogenous rural development in the EU, w: Handbook of Rural Studies, red. P. Cloke, T. Marsden, P. Mooney, SAGE Publications Ltd, London 2006, s. 278.

3 http://www.minrol.gov.pl/pol/Wsparcie-rolnictwa-i-rybolowstwa/PROW-2007-2013.

4 J. Misiąg, W. Misiąg, M. Tomalak, Ocena efektywności wykorzystania pomocy finansowej Unii Europejskiej jako instrumentu polityki spójności spoleczno-gospodarczej oraz poprawy warunków życia, Wyższa Szkoła Informatyki i Zarządzania z siedzibą w Rzeszowie, Rzeszów 2013. 
c) sektor, na który PROW wpłynął najbardziej to budownictwo (względem bazowego scenariusza: wzrost zatrudnienia wyższy o 4,6\% oraz PKB wyższy о $3,75 \%$ );

d) relatywnie duże korzyści dla PKB w handlu oraz przemyśle lekkim;

e) najsłabsze oddziaływanie środków alokowanych w ramach PROW 20072013 - w przypadku przemysłu paliwowego oraz wydobywczego;

f) największe korzyści z realizacji PROW mierzone PKB per capita (ogółem) zostaną zaobserwowane w 2014 roku i wyniosą prawie 120 euro (w cenach stałych z $2000 \mathrm{roku}$ ); w ostatnim okresie prognozy wartość realnego PKB per capita (ogółem) wyniesie ponad 8,7 tys. euro i będzie wyższa od scenariusza bazowego o 65 euro - dzięki wpływowi PROW;

g) realizacja PROW 2007-2013 przyczyni się do zwiększenia liczby miejsc pracy $\mathrm{w}$ gospodarce; docelowy poziom zatrudnienia $\mathrm{w}$ gospodarce zostanie osiągnięty z nawiązką; największy wpływ środków PROW 2007-2013 odnotowano dopiero w ostatnim roku realizacji (dodatkowe 220 tys. miejsc pracy);

h) do końca okresu wydatkowania funduszy ceny w rolnictwie będą rosły wolniej, a już po alokacji wszystkich środków tempo tychże cen będzie wyższe w porównaniu do CPI (Consumer Price Index); jednak w perspektywie 2020 roku łączny wzrost cen w rolnictwie w latach 2007-2020 będzie niższy o niespełna 0,4 p.p. w stosunku do wszystkich dóbr konsumenckich ${ }^{5}$.

W kolejnej perspektywie finansowej, w latach 2014-2020, publiczne wsparcie finansowe adresowane do polskiego rolnictwa i obszarów wiejskich ukierunkowane będzie na realizację celów określonych w „Strategii zrównoważonego rozwoju wsi, rolnictwa i rybactwa”. Strategia wyznacza także pięć celów szczegółowych: a) wzrost jakości kapitału ludzkiego, społecznego, zatrudnienia i przedsiębiorczości na obszarach wiejskich; b) poprawa warunków życia na obszarach wiejskich; c) bezpieczeństwo żywnościowe; d) wzrost produktywności i konkurencyjności sektora rolno-spożywczego; e) ochrona środowiska i adaptacja do zmian klimatu na obszarach wiejskich.

Wyznaczone cele na lata 2014-2020 są w zasadzie kontynuacją polityki poprzedniego PROW. Elementem różnicującym obie perspektywy programowania jest przyjęty na kolejne lata cel dotyczący adaptacji do zmian klimatu na

5 Ocena wplywu realizacji PROW 2007-2013 na gospodarkę Polski, Instytut Badań Strukturalnych, Warszawa, listopad 2011. 
obszarach wiejskich, jako reakcja na problemy związane z katastrofami naturalnymi i ich wpływem na infrastrukturę wsi oraz problemy w rolnictwie.

PROW na lata 2014-2020, jako II filar WPR, jest spójny z założeniami neoendogennego rozwoju oraz wpisuje się $\mathrm{w}$ ideę, a zwłaszcza $\mathrm{w}$ jeden $\mathrm{z}$ pięciu celów szczegółowych: „Wzrost jakości kapitału ludzkiego, społecznego zatrudnienia i przedsiębiorczości na obszarach wiejskich”. Można założyć, że podobnie jak w poprzednim okresie programowania, tak i w nowym - na lata 20142020, jeżeli Polska utrzyma się na pozycji lidera realizacji tego programu w Unii Europejskiej, wyeliminuje błędy i wykorzysta zdobyte doświadczenia, rozwój obszarów wiejskich będzie relatywnie dynamiczny, oparty na wzroście jakości kapitału ludzkiego, podniesieniu jakości życia na wsi oraz poprawieniu konkurencyjności sektora rolnego. W nowej perspektywie wyższa będzie pomoc na modernizację gospodarstw rolnych oraz będzie więcej pieniędzy dla młodych rolników niż w PROW 2007-2013. W stosunku do ubiegłego okresu Polska w ramach PROW będzie dysponowała kwotą wyższą o ok. 3,5 mld euro.

\section{Kierunki rozwoju rolnictwa i obszarów wiejskich}

Rolnictwo europejskie na tle rozwoju obszarów wiejskich, zgodnie z Europejskim Modelem Rolnictwa - MFA (Multifunctional Agriculture), rozwija się w dwóch, zupełnie rozbieżnych kierunkach. Pierwszy z nich powiązany jest z realiami ekonomicznymi, skoncentrowany na konkurencyjności tego sektora, zarówno na kontynencie europejskim, jak i na rynkach międzynarodowych. Druga opcja nakreśla kierunki rozwoju rolnictwa wielofunkcyjnego na tle koncepcji zintegrowanego rozwoju wsi i rolnictwa. Oznacza to zrównoważone gospodarowanie oparte na racjonalnym wykorzystaniu zasobów, łączącym interesy ludzi i przyrody ${ }^{6}$.

Wielofunkcyjność obszarów wiejskich powinna ogniskować się na przekształceniach w źródłach dochodów mieszkańców wsi, przy czym za najbardziej optymalną uznaje się sytuację, która wiąże się z zarobkowaniem poza rolnictwem. Termin ,wielofunkcyjność” bywa traktowany synonimicznie z takimi pojęciami, jak: „dywersyfikacja” oraz „wielozawodowość” (lub „wieloaktyw-

6 A. Kołodziejczak, Modele rolnictwa a zróżnicowanie przestrzenne sposobów gospodarowania $w$ rolnictwie polskim, Wydawnictwo Naukowe Uniwersytetu im. Adama Mickiewicza, Poznań 2010, s. 69-70. 
ność"). Dywersyfikacja powiązana jest z miejscem pracy i produkcji, co oznacza wytwarzanie więcej produktów i usług. $Z$ kolei wielofunkcyjność zawiera w sobie zarówno elementy dywersyfikacji, jak i aktywizacji oraz przedsiębiorczości społeczności wiejskiej w zakresie pozyskiwania dochodów w innych sektorach gospodarki (poza rolnictwem) ${ }^{7}$. Sytuację na polskiej wsi utrudnia mała liczba gospodarstw rozwojowych. Już teraz, w wielu wsiach województw: lubelskiego, małopolskiego, podkarpackiego, śląskiego i świętokrzyskiego obserwuje się brak gospodarstw na tyle mocnych i stabilnych ekonomicznie, aby mogły one przejąc ziemię sąsiadów nieprowadzących już działalności gospodarczo-rolniczej ${ }^{8}$.

Rozwój wielofunkcyjny umożliwia pozostawanie na wsi ludzi, zwłaszcza młodych i wykształconych, którzy nie muszą emigrować za pracą z powodu braku możliwości znalezienia zatrudnienia w rolnictwie. Główne cele, jakie realizuje rozwój wielofunkcyjny to: wspieranie przedsiębiorczości (zauważyć jednak należy, że „Rozwój zespołowej przedsiębiorczości na obszarach wiejskich zależy nie tylko od cech poszczególnych ludzi, ale również od społeczności lokalnych, mentalności czy wzorów społecznych"”); stymulowanie odpływu ludności z rolnictwa, przy równoczesnym zapobieganiu depopulacji wsi; wspomaganie procesu transformacji rolnictwa, które musi podołać wymogom konkurencji; powiązanie rozwoju gospodarczego z dbałością o środowisko ${ }^{10}$.

7 G. Krzyminiewska, Kultura ekonomiczna mieszkańców obszarów wiejskich. Problemy Przekształcenia - Wyzwania, Wydawnictwo Adam Marszałek, Toruń 2013, s. 97-99.

8 W. Michna, B. Chmielewska, A. Mierosławska, Zasięg $i$ konsekwencje zróżnicowania funkcji gospodarstw rolnych $w$ ujęciu przestrzennym, w: Zróżnicowanie regionalne $w$ rozwoju rolnictwa oraz jego wplyw na problemy ekonomiczne i spoleczne obszarów wiejskich (synteza), red. A. Sikorska, Instytut Ekonomiki Rolnictwa i Gospodarki Żywnościowej, Państwowy Instytut Badawczy, Warszawa 2010, s. 37.

9 A.J. Parzonko, Współczesne znaczenie przedsiębiorczości zespołowej w rolnictwie, w: Spoteczno-ekonomiczne determinanty rozwoju obszarów wiejskich, red. K. Krzyżanowska, Wydawnictwo SGGW, Warszawa 2012, s. 42.

10 M. Wieruszewska, Wieś polska. Konteksty. Kontrasty. Strategie, Instytut Rozwoju Wsi i Rolnictwa PAN, Warszawa 1997, s. 104. 


\section{Sytuacja polskiej wsi}

Rozważania nad perspektywą rozwoju obszarów wiejskich poprzedzę wnioskami wyłaniającymi się z raportu „Polska wieś 2012”" odnoszącymi się do obecnego stanu polskiej wsi. Na podkreślenie zasługuje fakt, że polska wieś staje się coraz bardziej atrakcyjna dla tych, którzy wybierają ją jako miejsce swojego zamieszkania. Autorzy raportu stwierdzają, że wieś staje się coraz mniej rolnicza wskutek rosnącej populacji wsi (obecnie ok. 60\%), nie mającej żadnego związku z produkcją rolniczą i użytkowaniem ziemi rolniczej. W odniesieniu do roli rolnictwa, jakie pełni ono w krajowej gospodarce - zmniejsza się jego udział w PKB (ok. 3\%). Wszystko wskazuje na to, że szanse na przetrwanie mają gospodarstwa znacznie większe od średnich w kraju (obecnie średnia ta wynosi ok. 10 ha). Liczba gospodarstw systematycznie maleje, zwłaszcza tych najmniejszych (do 2 ha), aczkolwiek należy zauważyć, że nadal wielu mieszkańców polskiej wsi, najczęściej ze względów sentymentalnych, nie pozbywa się swoich małych, kilkuhektarowych gospodarstw. Ostatnie dziesięciolecie, związane z dotacjami unijnymi, było najlepsze dla polskiej wsi w całej powojennej historii naszego kraju, w odniesieniu do dochodów w rolnictwie, które były dwukrotnie wyższe niż przed akcesją. Dotacje stanowią ponad 50\% dochodów rolników. Autorzy raportu zauważają jednak, że w wykorzystaniu środków unijnych ważniejsza jest ich absorpcja od odpowiedniej alokacji i efektywności zaangażowanych środków finansowych. Wspieranie przez UE rolnictwa i rolników, powiązane jest z koniecznością przestrzegania przez tych ostatnich, środowiskowych standardów produkcji rolnej (które są coraz ostrzejsze). Szczególnie promowanie jest rolnictwo i rozwój zrównoważony, w którym istotnym czynnikiem jest stan środowiska naturalnego. Taki kierunek rozwoju, spójny z polityką unijną, w niektórych przypadkach generuje pewne konflikty interesów - potrzeby rolników versus potrzeby środowiska naturalnego. Przykładem może być program „Natura 2000”. Obecnie, procesy demograficzne na wsi przebiegają podobnie jak w mieście, tzn. mieszkańcy wsi żyją coraz dłużej, podobne są również wskaźniki: dzietności, współczynniki urodzeń, umieralności niemowląt, wieku, w którym kobiety rodzą dzieci itp. Pomimo, iż od 2008 roku migracja ludności polskiej za granicę spada, to nadal poza krajem przeby-

11 Polska wieś 2012. Potencjat obszarów wiejskich szansa rozwoju, Biuletyn Forum Debaty Publicznej, nr 23, luty 2013. 
wa ok. 2 mln naszych rodaków, z których ok. jedną trzecią stanowią mieszkańcy wsi. Pomimo problemu starzejącego się społeczeństwa, wskaźnik starości ludności wiejskiej w Polsce należał w 2010 roku do najniższych w Unii Europejskiej. Natomiast statystyki dotyczące wskaźników bezrobocia na wsi nie prezentują się już tak optymistycznie. Powoduje to, większe niż w mieście, narażenie na życie w ubóstwie i wykluczenie społeczne. Zjawiska te mają różne natężenie ze względu na silny wpływ dziedzictwa historycznego, które - jako jeden z czynników - przyczyniło się do podziału terenów wiejskich naszego kraju na mniej lub bardziej rozwinięte. Najlepiej sytuacja przedstawia się w północnej i zachodniej części kraju, a najgorzej w części wschodniej, gdzie występuje proces depopulacji mający trwały charakter ${ }^{12}$.

\section{Perspektywy rozwoju polskiej wsi}

Zasady polityki rozwoju obszarów wiejskich UE na kolejną dekadę stanowią kontynuację rozwoju tychże obszarów według zasad zrównoważonego rozwoju, w oparciu o idę̨ rozwoju neoendogennego.

Wspólna Polityka Rolna, jako instrument kreowania rozwoju europejskich obszarów wiejskich, uwzględnia specyfikę rolnictwa, jako kluczowego sektora gospodarki w kontekście zaspokajania podstawowych potrzeb; aczkolwiek z ekonomicznego punktu widzenia - nieefektywnego - jeśli chodzi o wielkość PKB. Zatem „Jest czymś oczywistym, że polityka wobec obszarów wiejskich musi się różnić od większości innych polityk publicznych, które do niedawna miały charakter przede wszystkim polityk sektorowych, czego najlepszym przykładem jest polityka rolna. Polityka rozwoju obszarów wiejskich ma charakter polityki horyzontalnej, wielopłaszczyznowej, wielokryterialnej i przede wszystkim bardzo złożonej"13.

Przyszłość polskiej wsi, według prognoz GUS na 2030 rok, wiąże się ze znacznym wzrostem liczby jej ludności, spowodowanym szybką urbanizacją te-

12 O szczególnie trudnej sytuacji mieszkańców terenów wiejskich wschodniej Polski wspomniano również w książce: W. Knapik, Typy więzi społecznych a wzory współdziałania mieszkańców wsi w sytuacji ryzyka, zagrożenia i katastrofy powodzi, Wydawnictwo Uniwersytetu Rolniczego, Kraków 2013.

${ }_{13}$ J. Wilkin, Cele i zasady koordynacji polityk wspierajacych zrównoważony rozwój obszarów wiejskich, w: Rozwój obszarów wiejskich w Polsce a polityka spójności Unii Europejskiej. Stare problemy i nowe wyzwania (ze szczególnym uwzględnieniem woj. opolskiego), red. K. Heffner, Polska Akademia Nauk, Komitet Przestrzennego Zagospodarowania Kraju, Warszawa 2013, s. 26. 
renów wiejskich. Dotyczy to przede wszystkim terenów na obszarze do pięćdziesięciu kilometrów od granic większych miast. Przyrost ludności wiejskiej zanotują także inne, oddalone od wielkich miast tereny wiejskie, o przyjaznym i atrakcyjnym klimacie $\mathrm{w}$ wymiarze środowiskowo-wizualnym ${ }^{14}$. W tej perspektywie przyszłość polskiego rolnictwa związana jest z jego dywersyfikacją, która często łączona jest $\mathrm{z}$ wielozawodowością. W rolnictwie, oprócz zróżnicowania struktury produkcji i dochodów w gospodarstwie rolnym, dywersyfikacji ulegają również metody gospodarowania. Zgodnie z unijną perspektywą rozwoju obszarów wiejskich - metody te powinny być przyjazne dla środowiska naturalnego. Dywersyfikacja wyznacza kierunek rozwoju polityki rolnej, zarówno na szczeblu centralnym, jak i regionalnym. Polityka ta uwzględnia szerszy kontekst odnoszący się do obszarów wiejskich - aktywizację społeczności lokalnej, działania na rzecz ograniczania bezrobocia oraz polepszania jakości życia mieszkańców wsi ${ }^{15}$.

Szansą dla efektywniejszego rozwoju obszarów wiejskich, uwzględniając potrzebę jego wielofunkcyjności oraz dywersyfikacji, jest wsparcie się na endogennym potencjale lokalnych społeczności wykorzystującym miejscowe zasoby, np. walory krajobrazowe, lokalne produkty, marki służące kreowaniu specyfiki i wzmacnianiu przewagi konkurencyjnej mikroregionu, bazującej na „Wspólnych zasobach dóbr” (common-pool resources). W oparciu o „zakorzenione rynki" (nested markets) funkcjonują np. Lokalne Grupy Działania (LGD), wspierane poprzez dotacje unijne. Przyczyniają się do rozwoju lokalnego, zarówno w wymiarze społecznym, jak i ekonomicznym. Nowy okres programowania PROW na lata 2014-2020 stwarza równie atrakcyjne, jak w poprzednim okresie (2007-2013), warunki dla rozwoju LGD. Równie dynamicznie rozwijający się sektor usług agroturystycznych może być, w większym niż dotychczas stopniu, powiązany z ,zakorzenionymi rynkami” i wykorzystywać lokalny potencjał.

Prężnie rozwijająca się w ostatnich latach agroturystyka bazuje nie tylko na walorach turystyczno-krajobrazowych danego obszaru, które zapewnią zdrowy wypoczynek, ale również na regionalnym dziedzictwie, do którego na-

14 J. Wilkin, Lepszy świat - polska wieś za 25 lat, w: Polska wieś 2025. Wizja rozwoju, red.

J. Wilkin, Fundusz Współpracy, Warszawa 2005, s. 42.

15 Ibidem, s. 154. 
leży zaliczyć regionalną żywność i produkty tradycyjne ${ }^{16}$. Z racji tego, że polskie produkty regionalne są dostępne tylko na danym obszarze, wymagają stworzenia i wprowadzenia strategii marketingu regionalnego, aby wspomóc stworzenie marki nie tylko wśród obecnych, jak i potencjalnych odbiorców, co zapewni stały zbyt usług i dóbr na przynajmniej wystarczającym poziomie ${ }^{17}$. Warto jednak inwestować w promocję produktów i atrakcji regionalnych, które są szansą utrzymania, na względnie optymalnym poziomie, standardu życia mieszkańców wsi, zwłaszcza tych terenów, które zagrożone są depopulacją. Jak wspomniano wcześniej do takich regionów zalicza się polska „ściana wschodnia”. Odwołując się do badań przeprowadzonych w lipcu i sierpniu 2012 roku, w których wzięło udział 761 turystów odpoczywających w 75 ośrodkach agroturystycznych wybranych gmin wiejskich Lubelszczyzny i Podlasia, można skonkludować, że respondenci podczas wypoczynku, oprócz podejmowanej aktywności fizycznej, zainteresowani byli także bliższym poznaniem sfery kulturowej danego miejsca, poprzez np. uczestnictwo w festynach czy jarmarkach oraz degustację produktów lokalnej kuchni. Dodatkowo wśród młodszych badanych występowała też chęć poznania lokalnego rękodzieła, nie tylko poprzez zapoznawanie się, ale także poprzez udział $\mathrm{w}$ prowadzonych, specjalnych warsztatach $^{18}$.

\section{Podsumowanie}

Rozwój polskich obszarów wiejskich jest determinowany wpływem dwóch, głównych czynników: globalizacji oraz integracji wynikającej z przynależności do Unii Europejskiej. Globalizacja narzuca szybkie tempo zmian, które nie zawsze przebiegają zgodnie z zasadami zrównoważonego rozwoju, opartego na godzeniu ze sobą interesów gospodarczych, społecznych oraz ekologicznych. Polska, jako członek UE, przede wszystkim jest zobligowana do realizacji polityki wspólnotowej, która w przypadku rozwoju obszarów wiejskich, ukierun-

16 E. Świstak i in., Produkty regionalne jako element budowania konkurencyjności obszarów wiejskich, w: Budowanie konkurencyjności obszarów wiejskich, red. K. Krzyżanowska, Wydawnictwo SGGW, Warszawa 2013, s. 140.

17 A. Sieczko, Produkty tradycyjne i regionalne a marketing terytorialny, w: Budowanie konkurencyjności obszarów wiejskich, red. K. Krzyżanowska, Wydawnictwo SGGW, Warszawa 2013, s. 158

18 J. Zawadka, Zachowania turystów wypoczywajacych na wsi i czynniki je warunkujace, w: Budowanie konkurencyjności obszarów wiejskich, red. K. Krzyżanowska, Wydawnictwo SGGW, Warszawa 2013, s. 181. 
kowana jest na zrównoważony rozwój oraz wykorzystanie potencjału ekonomicznego i społecznego mikroregionów. Oddolne inicjatywy oraz partycypacja społeczeństwa lokalnego sprzyja nie tylko efektywniejszemu wykorzystaniu wszelkich zasobów, ale przyczynia się do budowania społeczeństwa obywatelskiego, w myśl idei neoendogennego rozwoju.

Jak podkreślił C. Ray - dla Europy neoendogenny rozwój oznacza nową jakość skoordynowanego zarządzania, wzrost znaczenia organizacji pozarządowych, co może - z jednej strony - oznaczać oportunizm wobec oficjalnej polityki, zaś z drugiej - wzrost oddolnych inicjatyw. Mechanizm neoendogenny powoduje, że zacierają bądź poszerzają się granice obszarów dzięki podejmowaniu inicjatyw wykraczających poza terytorium danej społeczności; może to również oznaczać ponadnarodową kooperację ${ }^{19}$.

Cele strategii UE w zakresie rozwoju obszarów wiejskich są zawarte we Wspólnej Polityce Rolnej, a jednym z jej instrumentów jest Program Rozwoju Obszarów Wiejskich. Z analizy realizacji zadań w ramach PROW na lata 20072013 wynika, iż Polska jako lider w zakresie absorpcji środków, zyskała wiele zarówno w sferze inwestycji, tworzenia nowych miejsc pracy, rozwoju usług i sektorów związanych ze wsią i rolnictwem, jak i w sferze społecznej związanej $\mathrm{z}$ budowaniem kapitału społecznego. PROW wpłynął również na wielofunkcyjny rozwój obszarów wiejskich, który aktywizuje społeczności lokalne w zakresie przedsiębiorczości skupiającej się na pozyskiwaniu dochodów poza rolnictwem. Taka polityka umożliwia dostosowanie się wsi do wymogów zglobalizowanej gospodarki, dając szansę mieszkańcom wsi na utrzymanie lub nawet wzrost jakości życia. Wielofunkcyjność obszarów wiejskich to model, który powinien wyznaczać główny kierunek rozwoju w nadchodzących latach. Znajduje to uzasadnienie w malejącej populacji wsi zajmującej się rolnictwem, odwrotnie do zainteresowania wsią jako miejscem zamieszkania. Dywersyfikacja rozwoju oraz jego wsparcie na lokalnych zasobach jest w dużym stopniu wymuszona przez UE, ale dla Polski jako dotychczasowego lidera $w$ absorpcji środków unijnych, oznacza to wymierne korzyści, zarówno gospodarcze, jak i społeczne. Można mieć nadzieję, że kolejne lata przyczynią się do dalszego rozwoju, a wspólne działania różnych aktorów społecznych oraz połączenie ich potencjału spowoduje efekt synergii.

19 C. Ray, Culture economies: a perspective on local rural development in Europe, Centre for Rural Economy, Dept. of Agricultural Economics and Food Marketing, University of Newcastle upon Tyne, 2001, s. 82-83. 


\section{Literatura}

Adamski T., Gorlach K., Koncepcja rozwoju neoendogennego, czyli renesans znaczenia wiedzy lokalnej, w: Socjologia jako stużba społeczna, red. K. Gorlach, M. Niezgoda, Z. Seręga, Wydawnictwo Uniwersytetu Jagiellońskiego, Kraków 2007.

http://www.minrol.gov.pl/pol/Wsparcie-rolnictwa-i-rybolowstwa/PROW-2007-2013.

Knapik W., Typy więzi społecznych a wzory wspótdziałania mieszkańców wsi w sytuacji ryzyka, zagrożenia i katastrofy powodzi, Wydawnictwo Uniwersytetu Rolniczego, Kraków 2013.

Kołodziejczak A., Modele rolnictwa a zróżnicowanie przestrzenne sposobów gospodarowania w rolnictwie polskim, Wydawnictwo Naukowe Uniwersytetu im. Adama Mickiewicza, Poznań 2010.

Krzyminiewska G., Kultura ekonomiczna mieszkańców obszarów wiejskich. Problemy Przekształcenia - Wyzwania, Wydawnictwo Adam Marszałek, Torun 2013.

Michna W., Chmielewska B., Mierosławska A., Zasięg i konsekwencje zróżnicowania funkcji gospodarstw rolnych w ujęciu przestrzennym, w: Zróżnicowanie regionalne w rozwoju rolnictwa oraz jego wplyw na problemy ekonomiczne i spoleczne obszarów wiejskich (synteza), red. A. Sikorska, Instytut Ekonomiki Rolnictwa i Gospodarki Żywnościowej, Państwowy Instytut Badawczy, Warszawa 2010.

Misiąg J., Misiąg W., Tomalak M., Ocena efektywności wykorzystania pomocy finansowej Unii Europejskiej jako instrumentu polityki spójności spoleczno-gospodarczej oraz poprawy warunków życia, Wyższa Szkoła Informatyki i Zarządzania z siedzibą w Rzeszowie, Rzeszów 2013.

Ocena wplywu realizacji PROW 2007-2013 na gospodarke Polski, Instytut Badań Strukturalnych, Warszawa, listopad 2011.

Parzonko A.J., Wspótczesne znaczenie przedsiębiorczości zespolowej w rolnictwie, w: Spoleczno-ekonomiczne determinanty rozwoju obszarów wiejskich, red. K. Krzyżanowska, Wydawnictwo SGGW, Warszawa 2012.

Polska wieś 2012. Potencjat obszarów wiejskich szansa rozwoju, Biuletyn Forum Debaty Publicznej, nr 23, luty 2013.

Ray C., Culture economies: a perspective on local rural development in Europe, Centre for Rural Economy, Dept. of Agricultural Economics and Food Marketing, University of Newcastle upon Tyne, 2001.

Ray C., Neo-endogenous rural development in the EU, w: Handbook of Rural Studies, red. P. Cloke, T. Marsden, P. Mooney, SAGE Publications Ltd, London 2006.

Sieczko A., Produkty tradycyjne i regionalne a marketing terytorialny, w: Budowanie konkurencyjności obszarów wiejskich, red. K. Krzyżanowska, Wydawnictwo SGGW, Warszawa 2013.

Świstak E. i in., Produkty regionalne jako element budowania konkurencyjności obszarów wiejskich, w: Budowanie konkurencyjności obszarów wiejskich, red. K. Krzyżanowska, Wydawnictwo SGGW, Warszawa 2013. 
Wieruszewska M., Wieś polska. Konteksty. Kontrasty. Strategie, Instytut Rozwoju Wsi i Rolnictwa PAN, Warszawa 1997.

Wilkin J., Cele i zasady koordynacji polityk wspierajacych zrównoważony rozwój obszarów wiejskich, w: Rozwój obszarów wiejskich w Polsce a polityka spójności Unii Europejskiej. Stare problemy i nowe wyzwania (ze szczególnym uwzględnieniem woj. opolskiego), red. K. Heffner, Polska Akademia Nauk, Komitet Przestrzennego Zagospodarowania Kraju, Warszawa 2013.

Wilkin J., Lepszy świat - polska wieś za 25 lat, w: Polska wieś 2025. Wizja rozwoju, red. J. Wilkin, Fundusz Współpracy, Warszawa 2005.

Zawadka J., Zachowania turystów wypoczywajacych na wsi i czynniki je warunkujace, w: Budowanie konkurencyjności obszarów wiejskich, red. K. Krzyżanowska, Wydawnictwo SGGW, Warszawa 2013.

\section{Changes in rural areas of Poland on the basis of Rural Development Programme 2014-2020}

\section{Summary}

Since 2004 the policy of development of Polish rural areas is connected to European Union (EU) regulations which indicate areas of development, its aims and priorities. The EU policy is realized by various means. One of them is Rural Development Programme (RDP). This paper presents the efficiency of utilizing the financial support from RDP in the previous financial period (2007-2013) an well as the aims of this programme in a new financial period (2014-2020). Concept of neo-endogenous development was used to describe the development of rural areas. This article presents the areas of development of agriculture and rural areas. The outlined perspective of development of Polish rural areas is based on their current situation and projected development connected to the concept of neo-endogenous development which take into account its multifunctionality and diversity.

Keywords: Rural Development Programme, neo-endogenous development, rural areas. 